\title{
ॠUSGS
}

science for a changing world

\section{Water-Quality and Geophysical Data for Three Study Sites within the Williston Basin and Prairie Pothole Region}

By Todd M. Preston, Bruce D. Smith, Joanna N. Thamke, and Tara Chesley-Preston

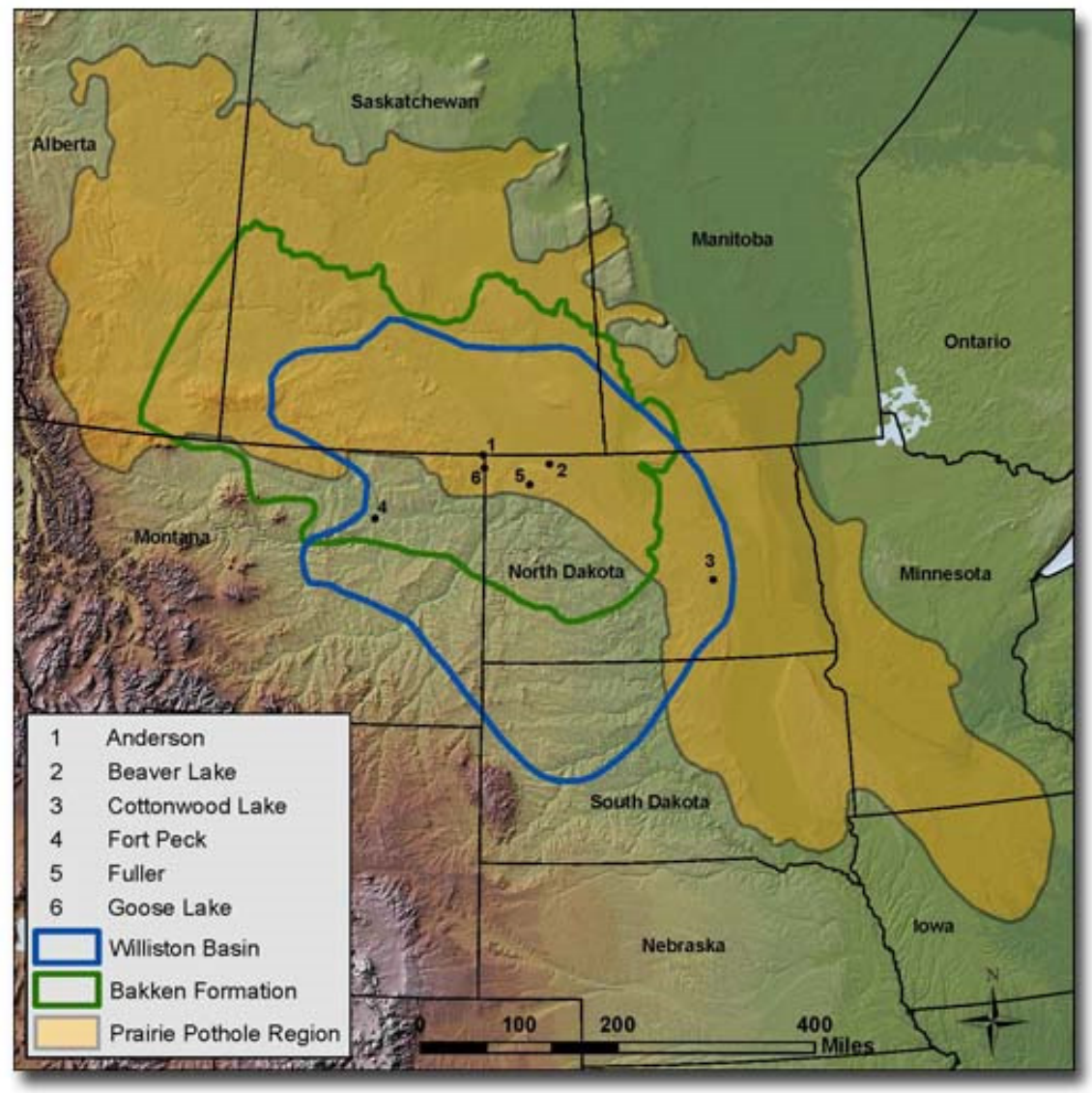

Open-File Report 2012-1149

U.S. Department of the Interior

U.S. Geological Survey 


\section{U.S. Department of the Interior \\ KEN SALAZAR, Secretary}

\section{U.S. Geological Survey \\ Marcia K. McNutt, Director}

U.S. Geological Survey, Reston, Virginia: 2012

For product and ordering information:

World Wide Web: http://www.usgs.gov/pubprod

Telephone: 1-888-ASK-USGS

For more information on the USGS-the Federal source for science about the Earth,

its natural and living resources, natural hazards, and the environment:

World Wide Web: http://www.usgs.gov

Telephone: 1-888-ASK-USGS

Suggested citation:

Preston, T.M., Smith, B.D., Thamke, J.N., and Chesley-Preston, T., 2012, Water-quality and geophysical data for three study sites within the Williston Basin and Prairie Pothole Region: U.S. Geological Survey Open-File Report 2012-1149, $17 \mathrm{p}$.

Any use of trade, product, or firm names is for descriptive purposes only and does not imply endorsement by the U.S. Government.

Although this report is in the public domain, permission must be secured from the individual copyright owners to reproduce any copyrighted material contained within this report. 


\section{Contents}

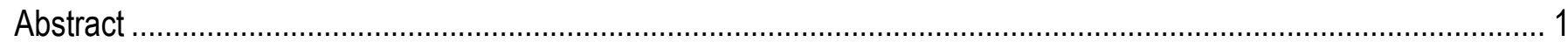

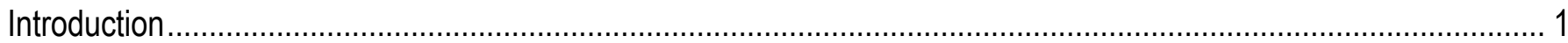

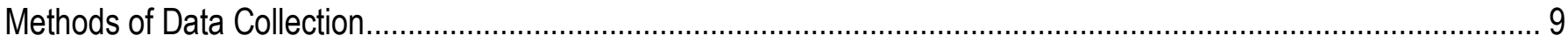

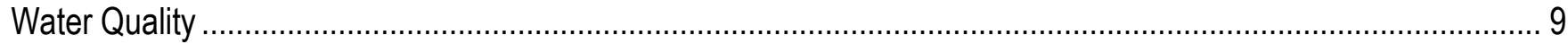

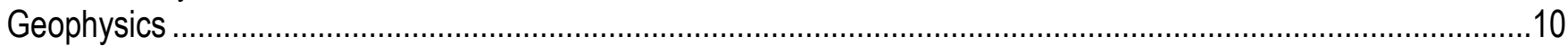

Geonics EM-31 Terrain Apparent Conductivity Meter..............................................................................10

Geonics EM-34 Terrain Apparent Conductivity Meter............................................................................14

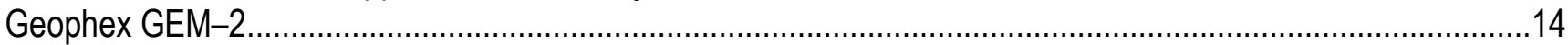

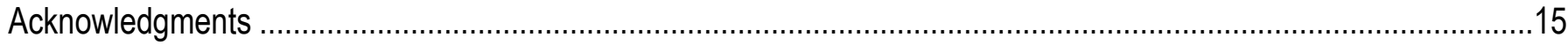

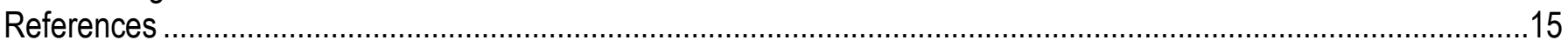

Appendix 1. Water-Quality and Geophysical Data (digital data) .......................................................................17

\section{Figures}

1. Map showing locations of three selected study sites, the Williston Basin, and the Prairie Pothole Region ............. 2

2. Map showing water-quality sample sites and surficial geology, Goose Lake study site, Montana .......................... 4

3. Map showing water-quality sample sites and surficial geology, Anderson study site, Montana .............................. 6

4. Map showing water-quality sample sites and surficial geology, Fuller study site, North Dakota ............................ 8

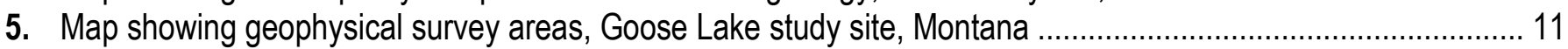

6. Map showing geophysical survey areas, Anderson study site, Montana …………………............................ 12

7. Map showing geophysical survey areas, Fuller study site, North Dakota......................................................... 13

\section{Tables}

1. Effective exploration depths for the Geonics EM-34

1-1. Water-quality data for Goose Lake study site, Montana, 1989-2009................................................... link

1-2. Water-quality data for Anderson study site, Montana, 2004, 2005, and 2010........................................... link

1-3. Water-quality data for Fuller study site, North Dakota, 2010 .............................................................. link

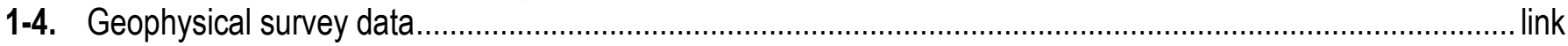




\section{Conversion Factors}

Inch/Pound to SI

\begin{tabular}{|c|c|c|}
\hline Multiply & By & To obtain \\
\hline \multicolumn{3}{|c|}{ Length } \\
\hline inch (in.) & 2.54 & centimeter $(\mathrm{cm})$ \\
\hline inch (in.) & 25.4 & millimeter (mm) \\
\hline foot (ft) & 0.3048 & meter $(\mathrm{m})$ \\
\hline mile (mi) & 1.609 & kilometer (km) \\
\hline \multicolumn{3}{|c|}{ Area } \\
\hline acre & 4,047 & square meter $\left(\mathrm{m}^{2}\right)$ \\
\hline acre & 0.4047 & hectare (ha) \\
\hline acre & 0.4047 & square hectometer $\left(\mathrm{hm}^{2}\right)$ \\
\hline acre & 0.004047 & square kilometer $\left(\mathrm{km}^{2}\right)$ \\
\hline square mile $\left(\mathrm{mi}^{2}\right)$ & 259.0 & hectare (ha) \\
\hline square mile $\left(\mathrm{mi}^{2}\right)$ & 2.590 & square kilometer $\left(\mathrm{km}^{2}\right)$ \\
\hline \multicolumn{3}{|c|}{ Volume } \\
\hline $\begin{array}{l}\text { barrel (bbl), (petroleum, } \\
1 \text { barrel=42 gal) }\end{array}$ & 0.1590 & cubic meter $\left(\mathrm{m}^{3}\right)$ \\
\hline \multicolumn{3}{|c|}{ Length } \\
\hline meter $(\mathrm{m})$ & 3.281 & foot $(\mathrm{ft})$ \\
\hline meter $(\mathrm{m})$ & 1.094 & yard (yd) \\
\hline \multicolumn{3}{|c|}{ Volume } \\
\hline liter (L) & 33.82 & ounce, fluid (fl. oz) \\
\hline liter (L) & 2.113 & pint (pt) \\
\hline liter (L) & 1.057 & quart (qt) \\
\hline liter (L) & 0.2642 & gallon (gal) \\
\hline
\end{tabular}

Temperature in degrees Celsius $\left({ }^{\circ} \mathrm{C}\right)$ may be converted to degrees Fahrenheit $\left({ }^{\circ} \mathrm{F}\right)$ as follows:

${ }^{\circ} \mathrm{F}=\left(1.8 \times{ }^{\circ} \mathrm{C}\right)+32$

Horizontal coordinate information is referenced to the insert datum name (and abbreviation) here, for instance, "North American Datum of 1983 (NAD 83)"

Altitude, as used in this report, refers to distance above the vertical datum.

Specific conductance is given in microsiemens per centimeter at 25 degrees Celsius $\left(\mu \mathrm{S} / \mathrm{cm}\right.$ at $\left.25^{\circ} \mathrm{C}\right)$.

Concentrations of chemical constituents in water are given either in milligrams per liter $(\mathrm{mg} / \mathrm{L})$ or micrograms per liter $(\mu \mathrm{g} / \mathrm{L})$. 


\title{
Water-Quality and Geophysical Data for Three Study Sites within the Williston Basin and the Prairie Pothole Region
}

\author{
By Todd M. Preston, Bruce D. Smith, Joanna N. Thamke, and Tara Chesley-Preston
}

\begin{abstract}
This report is a data release for water geochemical sample analyses and geophysical surveys for three sites within the Williston Basin and Prairie Pothole Region of Montana and North Dakota. The data collection sites and procedures are described.

\section{Introduction}

The Williston Basin (fig. 1) has been a leading domestic oil and natural gas producing area since the 1950s. To help supply current and future energy needs, recent improvements in oil and gas production methods has increased extraction from deeper and less-permeable units, such as the Bakken Formation, and has led to rapid and substantial growth in energy development throughout the Williston Basin. The Bakken Formation may hold 3.65 billion barrels of technically recoverable oil within the Williston Basin (Pollastro and others, 2008), the largest oil accumulation identified by the U.S.

Geological Survey (USGS) in the lower 48 States. Estimates suggest that older oil fields produce at least 10 barrels of brine (greater than 35,000 milligrams per liter [mg/L] dissolved-solids concentration) per barrel of extracted oil (Wanty, 1997). Much of this brine, which has a dissolved-solids concentration that can exceed 380,000 mg/L (Iampen and Rostron, 2000), has been injected into deep geologic units by disposal wells. Some of the brine has been directed to storage and evaporation pits. Previous investigations (Murphy and Kehew, 1984; Reiten and Teschmak, 1993; Thamke and Craigg, 1997; Smith and others, 2006; Peterman and others, 2010) have identified brine contamination to surface water and shallow groundwater within the Williston Basin.
\end{abstract}




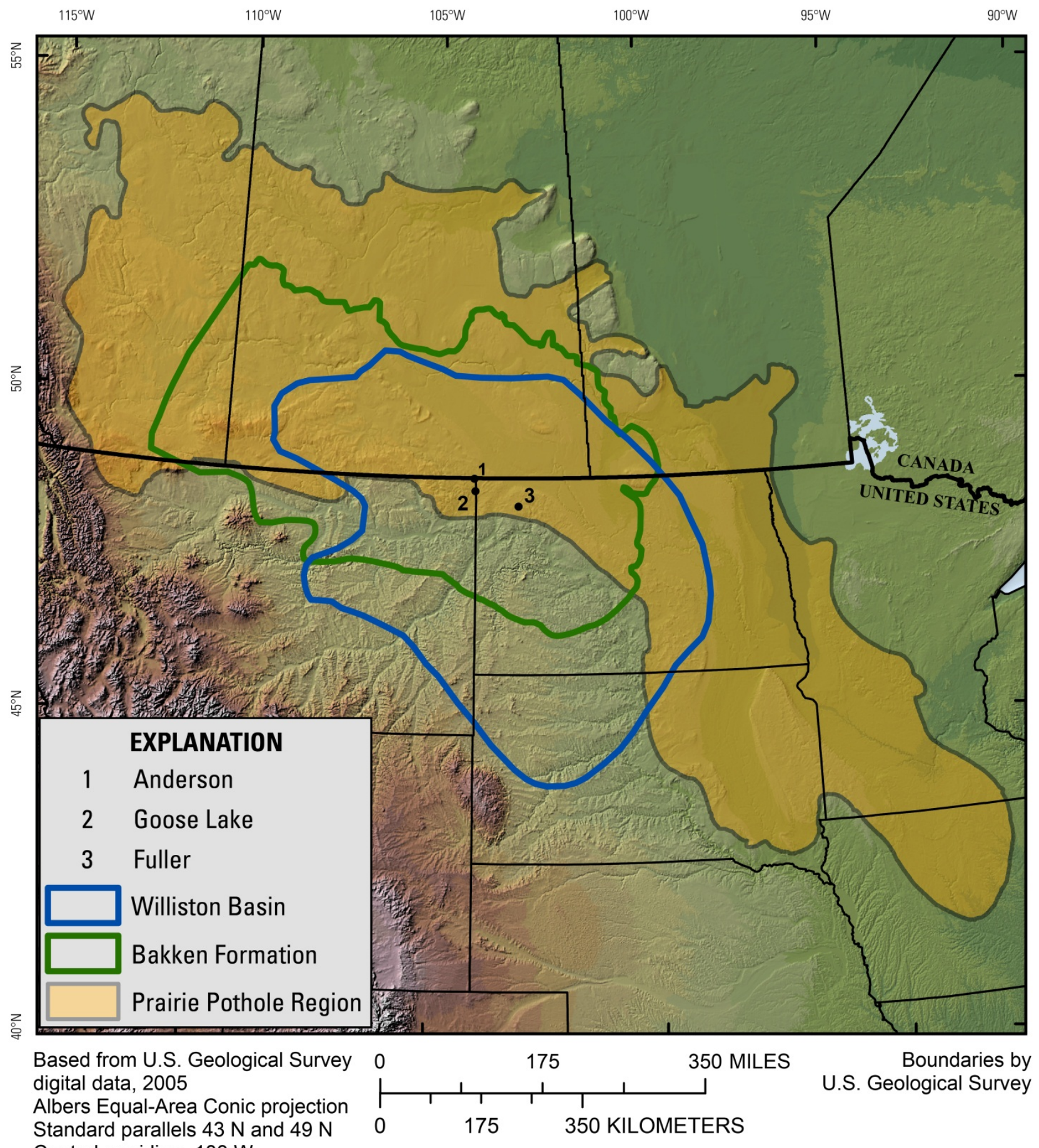

Central meridian $-103 \mathrm{~W}$

Figure 1. Map showing locations of three selected study sites, the Williston Basin, and the Prairie Pothole Region. 
The Prairie Pothole Region (PPR; fig. 1) is characterized by abundant wetlands that are critical habitat for North America's migratory waterfowl and other wildlife. The PPR covers much of the northeastern half of the Williston Basin. Depending on specific counties, approximately 50-90 percent of PPR wetlands have been drained and converted to cropland or otherwise altered by human activities (Dahl, 1990), placing greater importance on understanding the possible effects of brine contamination on the remaining wetland habitat.

In 2008, the USGS established a Science Team about Energy and Prairie Pothole Environments (STEPPE; http://steppe.cr.usgs.gov/) that included representatives from the USGS, U.S. Fish and Wildlife Service (USFWS), Montana Bureau of Mines and Geology (MBMG), and Sheridan County Conservation District (SCCD) to identify agency needs towards understanding the environmental effects of energy use in the PPR. In response to discussions among the STEPPE, the USGS initiated a study of brine contamination to Prairie Potholes from energy development in the Williston Basin funded by the USGS Central Region Integrated Science Program (CRISP) and other internal USGS program funds.

This report presents the water-quality and geophysical data collected at three selected sites near or within USFWS Waterfowl Production Areas (WPAs) in northeastern Montana and western North Dakota. Data were collected during 2009 and 2010 by the USGS, USFWS, MBMG, and SCCD to provide information in areas that represent the three primary depositional environments of the glaciated PPR: till, lacustrine, and outwash. Data collected during previous investigations at these sites also are included in this report.

Interpretation of these data has been given in oral and poster presentations (Preston and ChelseyPreston, 2012; Gleason and others, 2011; Preston and others, 2011; Tangen and others 2011; Smith and others, 2009). Copies of the presentations are given at http://steppe.cr.usgs.gov/pres.html (accessed February 2012).

The National Wildlife Refuge System includes several thousand WPAs that preserve wetlands and grasslands critical to providing breeding and nesting habitat to millions of waterfowl (U.S. Fish and Wildlife Service, 2007). WPAs consist of small depressions formed by receding glaciers. These depressions are bordered by wetland grasses and filled with aquatic life. Nearly 500 WPA units form a series of wetlands throughout traditional waterfowl ranges, 95 percent of the WPAs are located in the PPR (U.S. Fish and Wildlife Service, 2007).

The Goose Lake study site includes the Rabenberg WPA (fig. 2) and is located in and adjacent to T. 36 N., R. 58 E., sec. 27 in Sheridan County, northeastern Montana. The study site is located within the Medicine Lake National Wildlife Refuge and Goose Lake oilfield. Data were collected in an area that encompassed the entire square-mile section and parts of adjacent sections. Land-surface topography is hummocky and generally slopes to the east. Surficial geologic deposits include glacial till and outwash (fig. 2). Two outwash channels transport groundwater in a south and east direction toward the west arm of Goose Lake. Monitoring wells were installed during 1988-89 by the MBMG. 


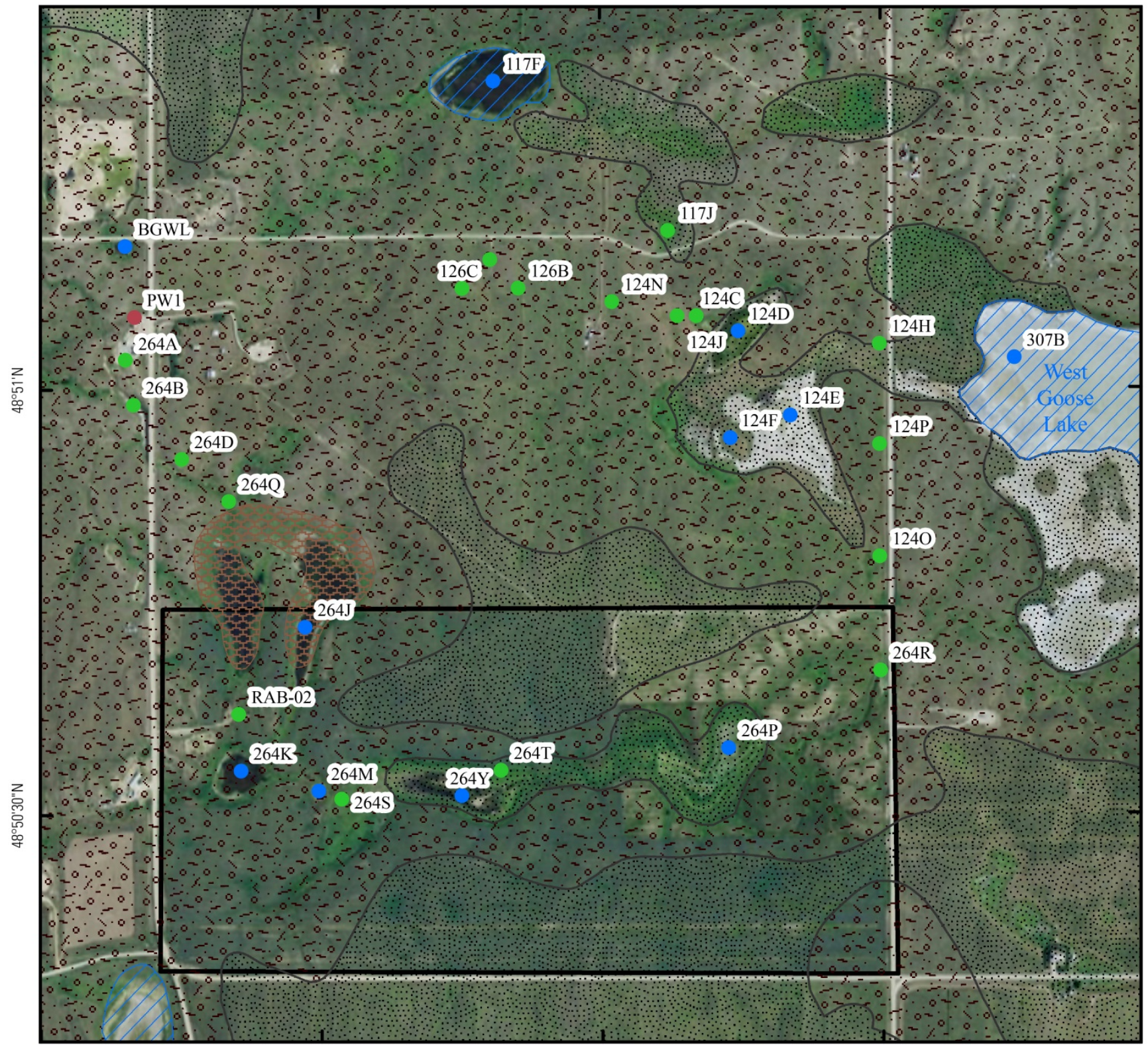

Base map data USDA Farm Service Agency digital data, 2009

Albers Equal-Area Conic projection Standard parallels $43 \mathrm{~N}$ and $49 \mathrm{~N}$ Central meridian $-103 \mathrm{~W}$

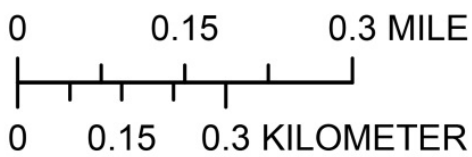

Boundaries by U.S. Fish Wildlife Service Geologic Map from Reiten, in press

\section{EXPLANATION}

Water Quality Well Locations

- Brine tank (number indicates label)

- Well (number indicates label)

- Wetland (number indicates label)

Rabenberg Waterfowl Production Area

\section{Surficial Geology}

Glacial lake

$.0 \div$ Glacial outwash

Glacial till

監琵 Quaternary alluvium Z Water

Figure 2. Map showing Rabenberg Waterfowl Production Area, water-quality sample sites and surficial geology, Goose Lake study site, Montana. 
The Anderson study site includes the Anderson WPA and is located in most of T. 37 N., R. 58 E., sec. 05 within Sheridan County, northeastern Montana (fig. 3). The study site is located in the Medicine Lake National Wildlife Refuge and Flat Lake oil field. Data were collected throughout the entire square-mile section and adjacent to the section. Land-surface topography is hummocky and generally slopes to the east. Surficial geologic deposits are primarily glacial till and outwash (fig. 3). One outwash channel bisects the area from the southwestern corner to the northeast and likely transports groundwater in a northeastern direction. Monitoring wells were installed during 2005 by the USFWS. 


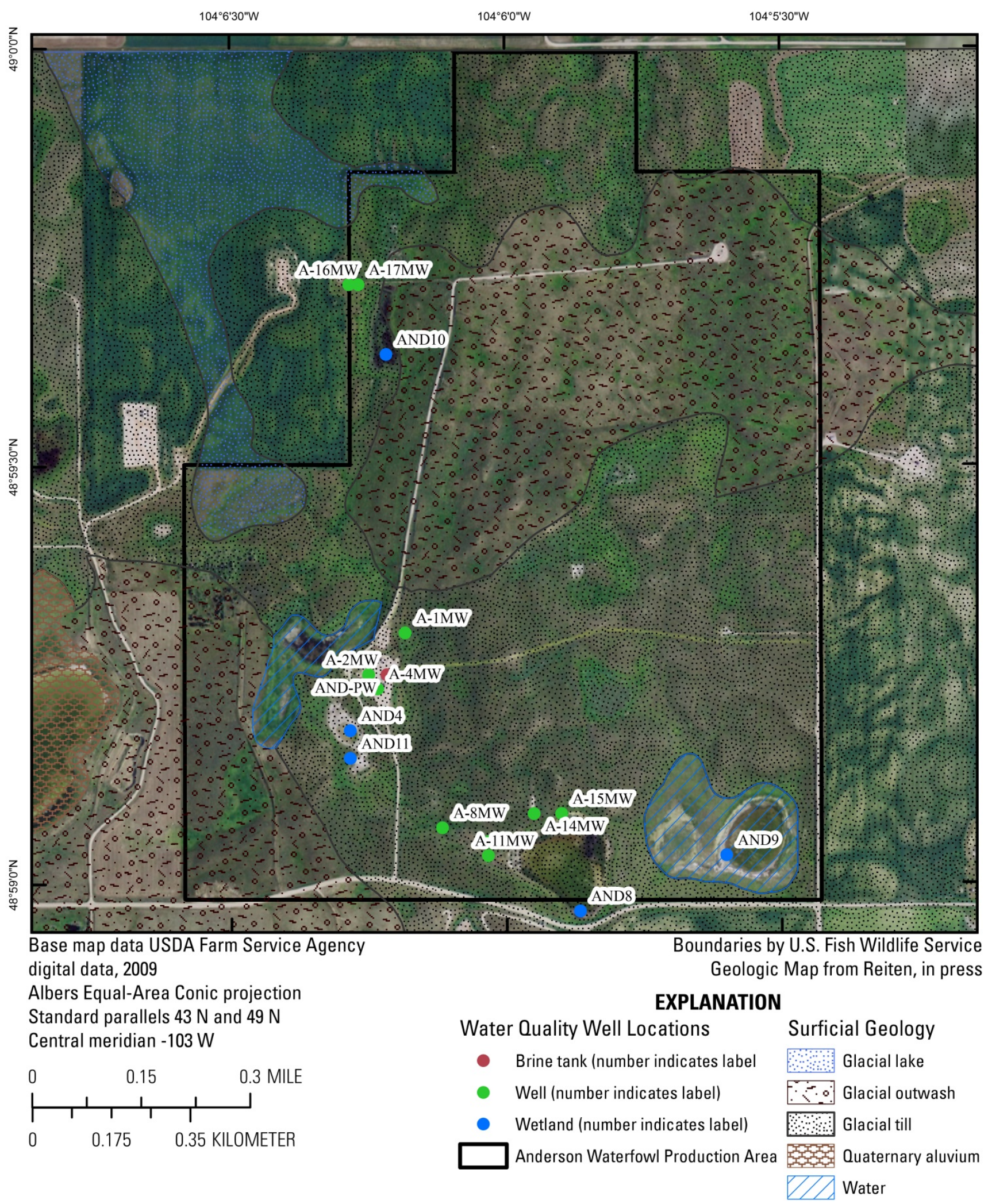

Figure 3. Map showing water-quality sample sites and surficial geology, Anderson study site, Montana. 
The Fuller study site includes part of the Fuller WPA and is located primarily in T. 159 N., R. 96 W., sec. 36 within Williams County, northwestern North Dakota (fig. 4). The study site is located within the Crosby Wetland Management District and Temple oil field. Data were collected in the southwestern part of the section and at nearby oil-production wells to the east and northwest of the Fuller WPA. Land-surface topography is flat and generally slopes to the west. Surficial geologic deposits are primarily outwash terrace and adjacent glacial lake sediments (fig. 4). Monitoring wells were installed during 2010 by the USGS. 


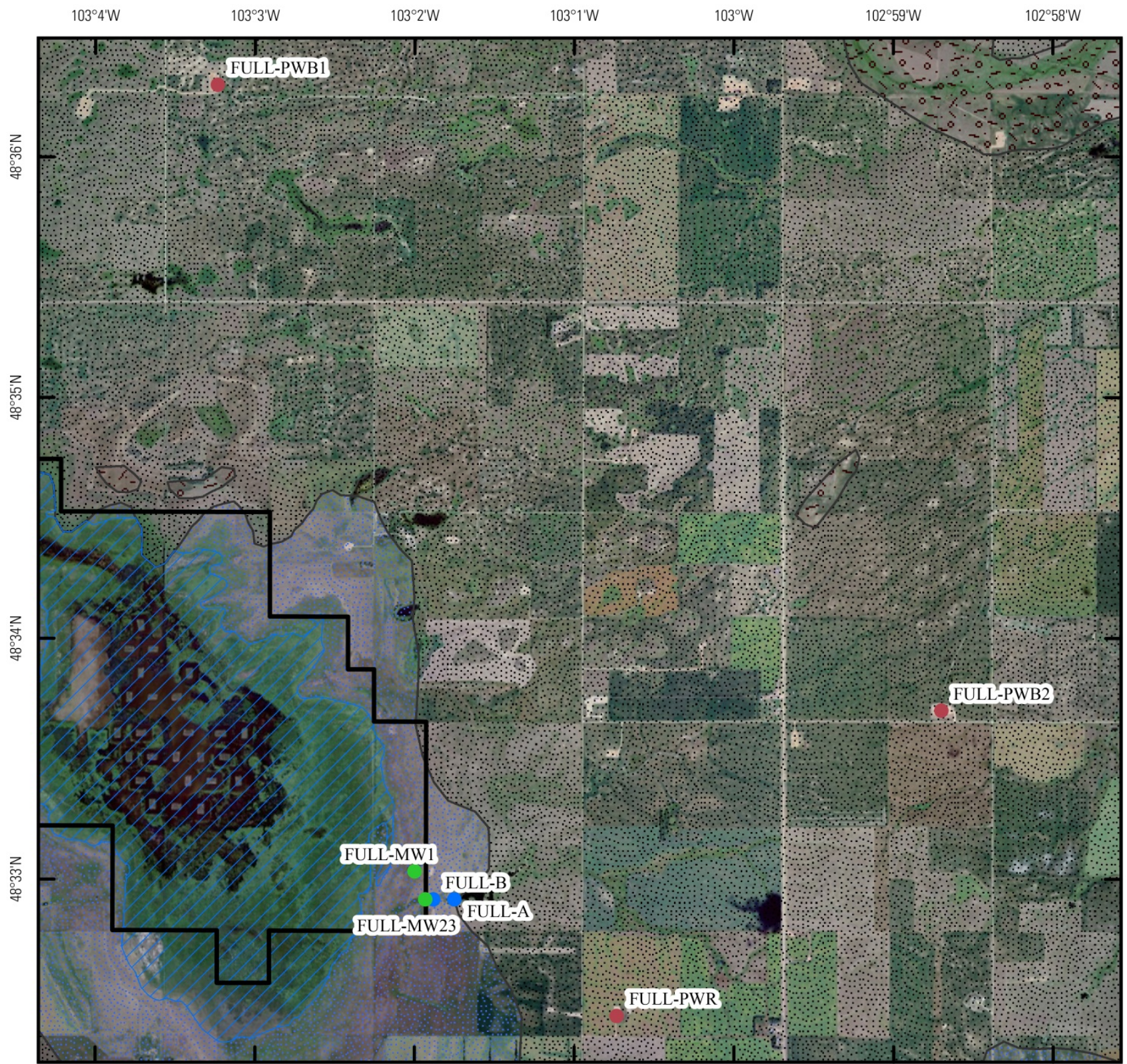

Base map data USDA Farm Service Agency digital data, 2009

Albers Equal-Area Conic projection Standard parallels $43 \mathrm{~N}$ and $49 \mathrm{~N}$ Central meridian $-103 \mathrm{~W}$

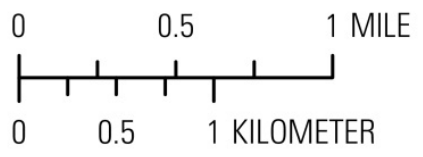

Boundaries by U.S. Fish Wildlife Service Geologic Map from North Dakota Geological Survey Bulletin 48

EXPLANATION
Water Quality Well Locations
Brine tank (number indicates label)
Well (number indicates label)
Wetland (number indicates label Glacial lake
Fuller Waterfowl Production Area

Figure 4. Map showing water-quality sample sites and surficial geology, Fuller study site, North Dakota. 


\section{Methods of Data Collection}

\section{Water Quality}

Water samples were collected from monitoring wells, wetlands, and oil/brine separation tanks at the Goose Lake study site during June 2009 (table 1A), at the Anderson study site during June 2010 (table 1B), and at the Fuller study site during June 2010 (table 1C). Historical water-quality data collected at the study sites prior to this investigation are included in tables 1A and 1B. Monitoring wells were purged until at least three well volumes of water were removed and parameters measured onsite ( $\mathrm{pH}$, water temperature, and specific conductance) had stabilized. Groundwater samples were collected using a 2-inch (in.) submersible pump at the Goose Lake study site and a peristaltic pump with flexible downhole hose at the Anderson and Fuller study sites.

Wetlands were sampled using a discrete sampling method modified from Knapton (1985). All of the wetland sites were shallow (typically less than 1.5 meters [m] deep) and are presumed to be well mixed by wind-generated turbulence, so a single sampling location for each wetland water sample was assumed to be representative of the entire wetland. Prior to sample collection, specific conductance was measured at various locations along the perimeter of the wetland to confirm adequate mixing. Samples were collected by wading to as deep as possible at a location. An acid-rinsed 4-liter polyethylene bottle was submersed upwind from the sample-collecting person, and the lid was removed after submersion to fill the bottle. Brine samples were collected from a spigot located below the oil/brine separator tank. Each brine sample was collected in a disposable acid-rinsed 4-liter polyethylene bottle.

Quality-control data to document the reproducibility of analytical results and any sample contamination were provided by test samples that consisted of a replicate sample or a field-blank sample incorporated into the sample set. Quality-control samples comprised about 10 percent of the total number of samples submitted by the USGS for analysis. Replicate samples are two or more samples considered to be essentially identical in composition. Replicate samples were collected in the field by concurrently filling sample bottle sets. Field blanks are aliquots of deionized water that are processed through the sampling equipment used to collect the environmental samples. These blanks then are subjected to the same processing as the environmental samples.

Sample processing, filtration, and preservation were performed in the field using methods described by USGS (variously dated). Samples were submitted to the USGS National Water Quality Laboratory in Denver, Colo., for analysis of major ions and selected halides using methods described by Fishman and Friedman (1989). Samples were submitted to the USGS Strontium Isotope Laboratory in Denver, Colo., for analysis of strontium isotopes, major ions, and trace elements. Major dissolved ions were analyzed by ion chromatography (IC) following appropriate dilutions and use of standards in the range of the sample concentrations. Trace metals were determined by inductively coupled plasma mass spectrometry (ICPMS). Analytical uncertainties by IC and ICPMS are typically in the range of 5 to 10 percent of the reported value at the 95 -percent confidence level. Strontium isotope ratios $(87 \mathrm{Sr} / 86 \mathrm{Sr})$ were measured on a Finnigan MAT 262 thermal ionization mass spectrometer using a double filament mode of evaporation and ionization of the sample. Instrumental fractionation was eliminated by adjusting the measured $88 \mathrm{Sr} / 86 \mathrm{Sr}$ ratio to a value of 8.3752 and correcting the $87 \mathrm{Sr} / 86 \mathrm{Sr}$ ratio accordingly. A strontium standard representing the isotopic value of modern sea water (EN-1) is run several times with each turret of samples. Using the measured $87 \mathrm{Sr} / 86 \mathrm{Sr}$ of this standard, the sample $87 \mathrm{Sr} / 86 \mathrm{Sr}$ ratios are adjusted to a scale on which seawater has a value of 0.709200 . The uncertainty in the adjusted $87 \mathrm{Sr} / 86 \mathrm{Sr}$ ratio is 0.00003 at the 95 -percent confidence level. 


\section{Geophysics}

\section{Geonics EM-31 Terrain Apparent Conductivity Meter}

A Geonics EM-31 terrain conductivity system was used to conduct geophysical surveys to determine the lateral dimensions of saline contaminated groundwater plumes at all three study sites. Geophysical surveys were performed at the Goose Lake study site in July and August 2004 and September and October 2009 (fig. 5, table 1D); at the Anderson study site in July and September 2004 (fig. 6, table 1D) and October 2010; and at the Fuller study site in October 2010 (fig. 7, table 1D). The EM-31 has a fixed coil array spaced $3.66 \mathrm{~m}$ apart, housed in a $4 \mathrm{~m}$ boom and operates at 9.8 kilohertz $(\mathrm{KHz})$. Apparent conductivity measurements were obtained in the vertical dipole orientation, which provides an exploration depth (ED) of approximately $6 \mathrm{~m}$ (McNeil, 1980), with measurements recorded in a Trimble GeoXT Global Positioning System (GPS) using ArcPad software. This device continuously monitors apparent conductivity as the boom is carried overland, with readings made at user selected locations. Survey lines and station locations in 2004 at the Goose Lake and Anderson study sites did not follow any regular (grid) pattern and generally had a greater number of measurements per area than the 2004, 2009, and 2010 surveys. Because of the confined nature of some contaminant plumes within coulees and draws at the Goose Lake study site, the spacing between measurements in 2009 was variable in these topographic features but never exceeded $30 \mathrm{~m}$. Otherwise, measurements were collected in a grid pattern determined from pacing and the relative position to the previous survey line on the Trimble GPS display using $30 \mathrm{~m}$ spacing at the Goose Lake study site in 2009 and $15 \mathrm{~m}$ spacing at the Anderson and Fuller study sites in 2010. A total of 589 and 2,094 apparent conductivity measurements were obtained at the Goose Lake and Anderson study sites in 2004, respectively. Apparent conductivity measurements were collected from 765, 609, and 494 station locations at the Goose Lake, Anderson, and Fuller study sites, respectively, in 2009 and 2010. The spatially interpolated surfaces from the EM-31 surveys at the Goose Lake study site cover an area of 43.8 and 195.7 acres in 2004 and 2009, respectively. Similarly, spatially interpolated surfaces from EM-31 apparent conductivity measurements in 2004 and 2010 at the Anderson study site cover an area of 76.6 and 52.1 acres, respectively. The spatially interpolated surface from EM-31 measurements at the Fuller study site in 2010 covers an area of 38.2 acres. All spatially interpolated surfaces were limited to buffers placed around the measurement points in ArcGIS 9.3.1, with the buffer distance varying from 25-60 m. The lowest buffer distance that did not leave gaps was selected for each spatially interpolated surface. 


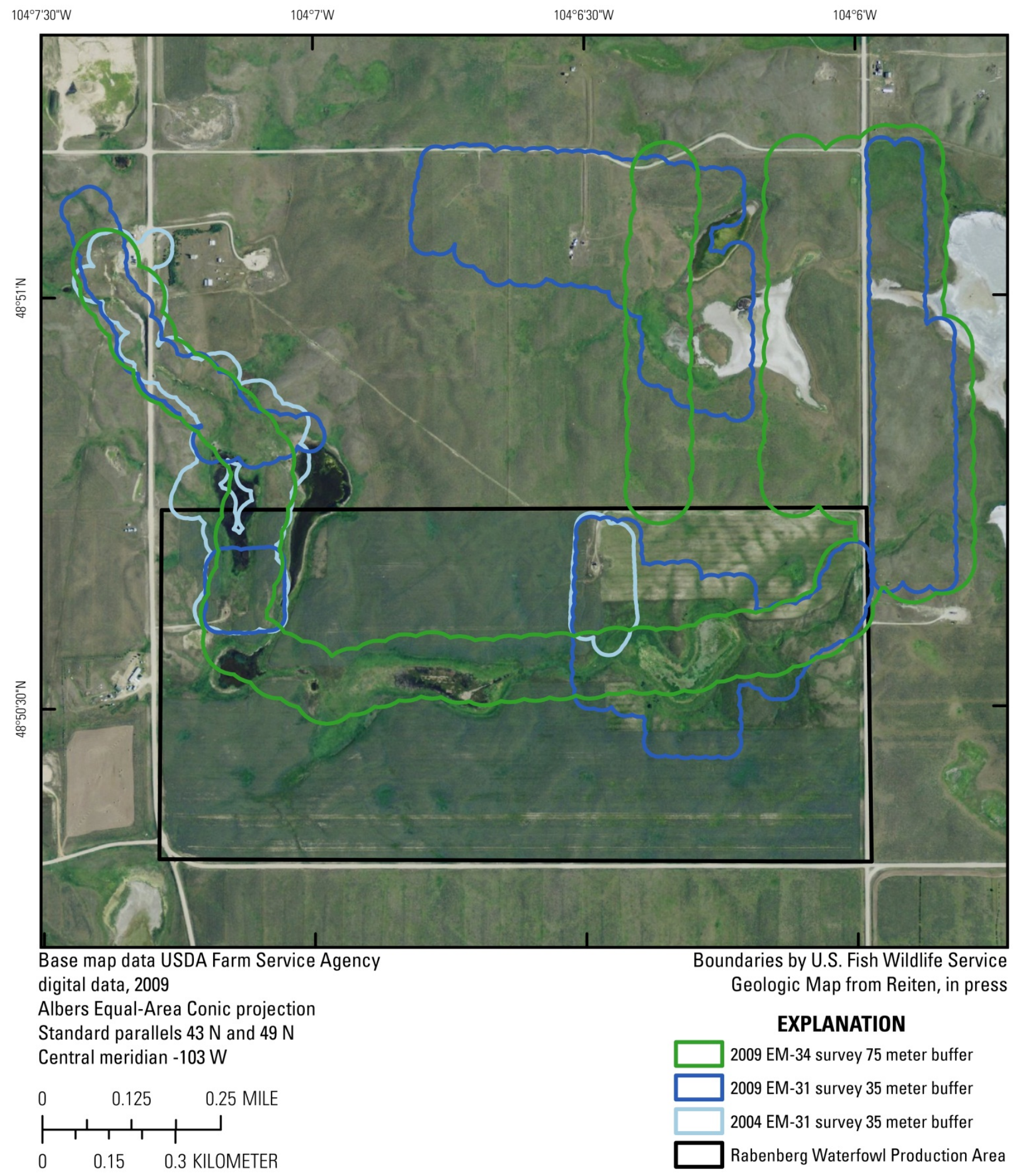

Figure 5. Map showing geophysical survey areas, Goose Lake study site, Montana. 


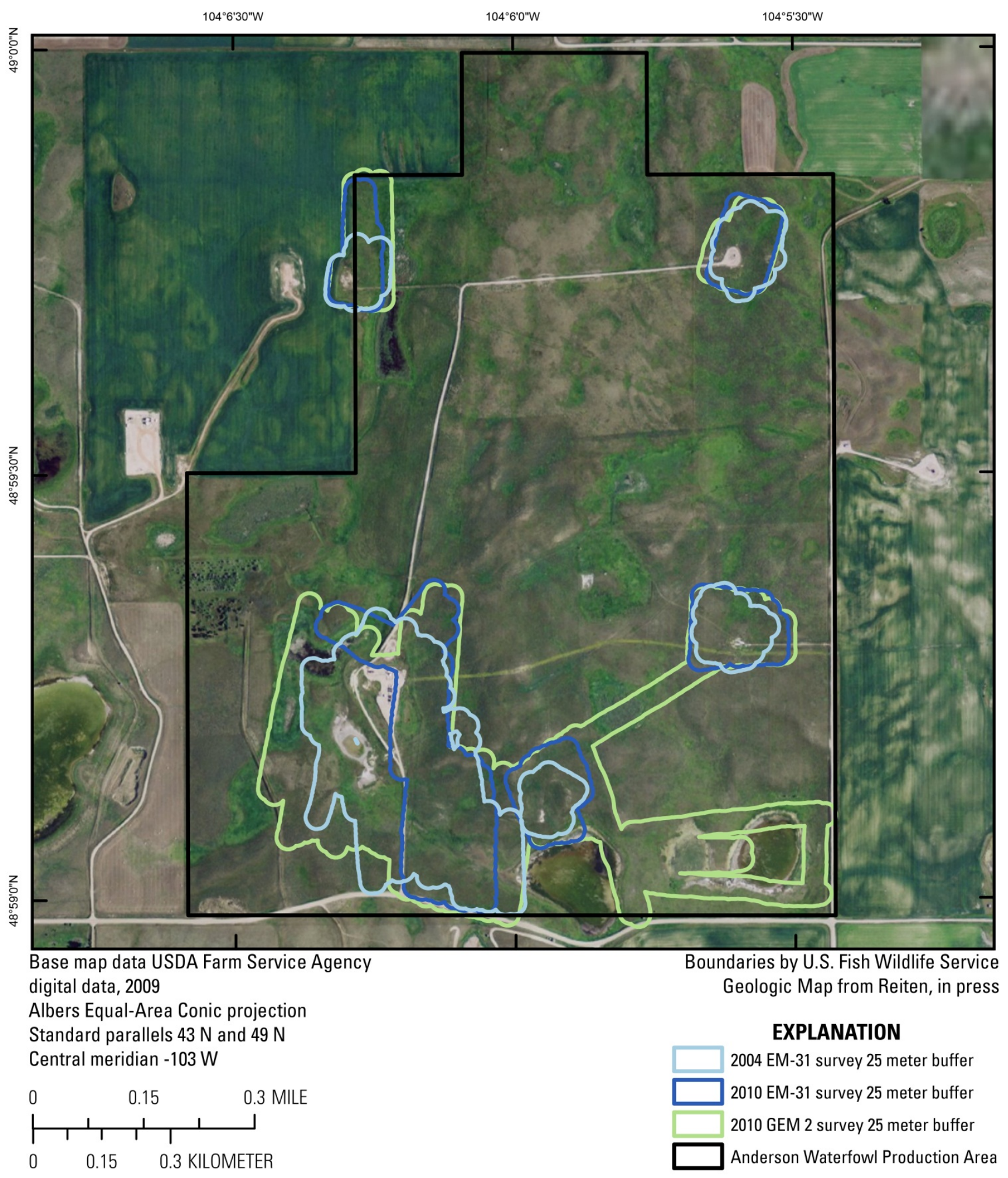

Figure 6. Map showing geophysical survey areas, Anderson study site, Montana. 


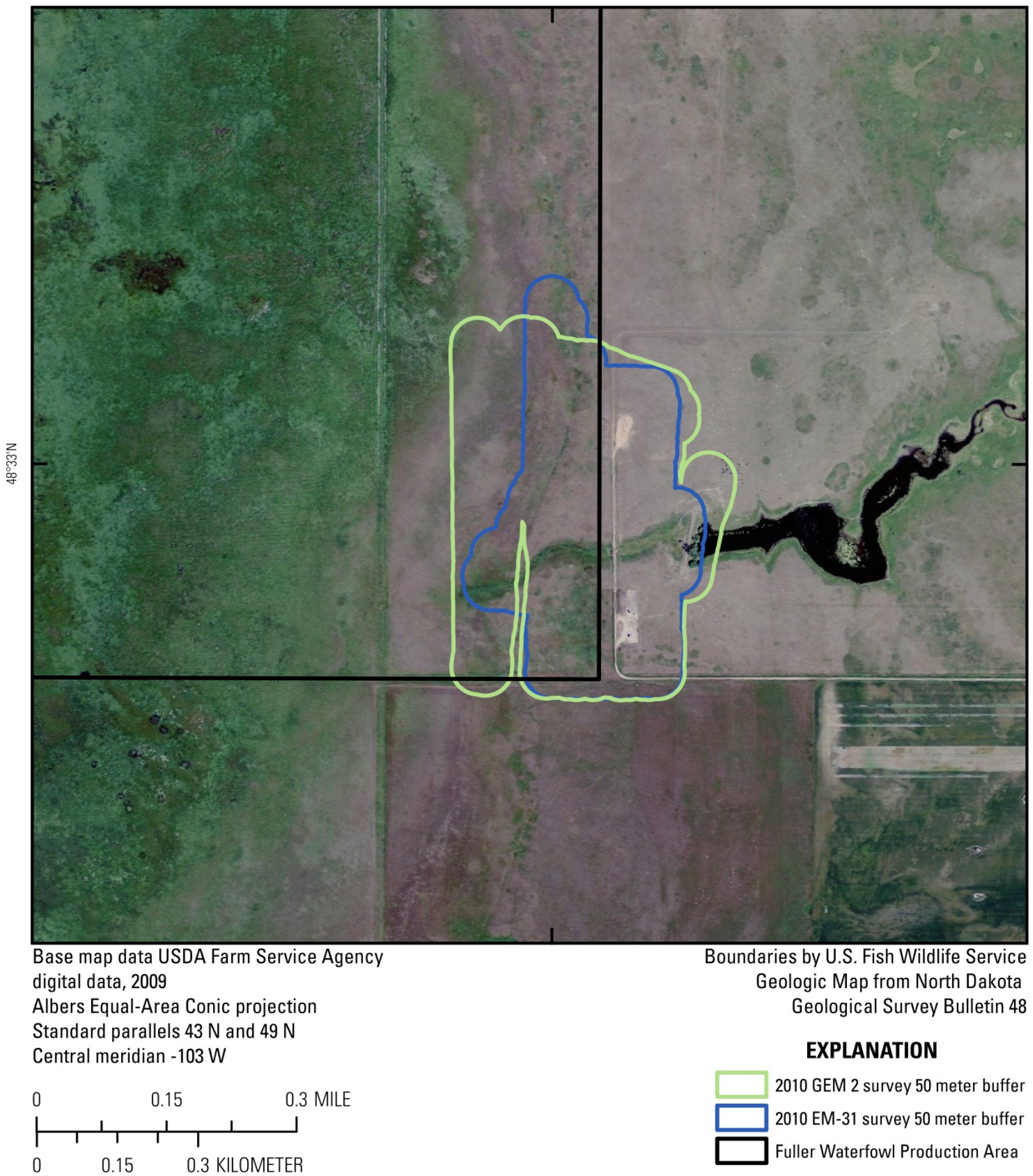

Figure 7. Map showing geophysical survey areas, Fuller study site, North Dakota. 


\section{Geonics EM-34 Terrain Apparent Conductivity Meter}

A Geonics EM-34 terrain conductivity system, owned by the USGS Montana Water Science Center, was used to characterize the depth profile of saline contamination groundwater plumes at the Goose Lake study site on September 15 and 17, 2009 (fig. 5, table 1D). The EM-34 is comprised of a receiver and transmitter coil connected by a 40-m reference cable and allows up to six apparent conductivity measurements to be taken at each station location by utilizing three different intercoil spacings in the horizontal and vertical dipole orientations. The transmitter and receiver intercoil spacings are 10, 20 and $40 \mathrm{~m}$, with operating frequencies of 6.4, 1.6, and $0.4 \mathrm{KHz}$, respectively. Circular bubble levels were affixed to the coils to ensure proper alignment in the field during measurements. The ED of the EM-34 depends on the intercoil spacing and dipole orientation, providing a range of 7.5-60 m (McNeill, 1980, table 1). EM-34 measurements were obtained at 60-m spacings, measured with a "wheel tape" in the field, and recorded in a Trimble GeoXT GPS using ArcPad software. Although six measurements were attempted at all 125 sampling sites, various factors including interference from pipelines, fences, data entry, and soil properties resulted in several unsuccessful readings. A total of 124 conductivity measurements was collected in the 10- and 20-m horizontal dipole maps, and 125 measurements in the 40-m horizontal dipole map. Vertical dipole measurements were obtained from 119, 118, and 115 station locations for the 10-, 20-, and 40-m intercoil spacings, respectively. The spatially interpolated surfaces from the 2009 EM-34 surveys at the Goose Lake detailed study site were created from a buffer $75 \mathrm{~m}$ around the measurement points and cover an area of 228.7 acres.

Table 1. Effective exploration depths for the Geonics EM-34 using different intercoil spacings and dipole orientations (McNeill, 1980).

\begin{tabular}{|ccc|}
\hline \multirow{2}{*}{$\begin{array}{c}\text { Intercoil spacing } \\
\text { (meters) }\end{array}$} & \multicolumn{2}{c|}{ Exploration depth (meters) } \\
\cline { 2 - 3 } & Horizontal dipoles & Vertical dipoles \\
\hline 10 & 7.5 & 15 \\
20 & 15 & 30 \\
40 & 30 & 60 \\
\hline
\end{tabular}

\section{Geophex GEM-2}

A Geophex GEM-2 operated in the frequency domain mode was used to characterize the depth profile of saline contamination groundwater plumes on October 14 and 16, 2010 at the Anderson study site (fig. 6, table 1D) and on October 15, 2010 at the Fuller study site (fig. 7, table 1D). The GEM-2 consists of a 1.6-m "ski" that contains a transmitter, receiver, and bucking coil that cancels the primary magnetic field in the receiving coil leaving just the secondary magnetic field. The transmitter coil creates a user specified multifrequency waveform using the pulse-width modulation technique with the receiving coil measuring the in-phase and quadrature components of the primary and secondary magnetic field, which can be converted to apparent conductivity. All GEM-2 surveys were conducted in the vertical dipole orientation and used seven frequencies: 1,530, 8,250, 23,070, 33,070, 47,970, 66,030, 
and 93,030 hertz $(\mathrm{Hz})$, providing effective exploration depths up to $30 \mathrm{~m}$. Apparent conductivity measurements and geographical coordinates were stored continuously across survey lines using a WAS enabled, Garmin 1800, with approximately seven measurements collected per meter, resulting in 368,580 and 105,932 measurements at the Anderson and Fuller study sites, respectively. The distance between survey lines was generally within $15 \mathrm{~m}$ of each other.

\section{Acknowledgments}

The data collection for this project required the efforts of the Science Team about Energy and Prairie Pothole Environments (STEPPE, http://steppe.cr.usgs.gov/). In addition to the authors, the scientists who worked on this project included the following:

Montana Bureau of Mines and Geology

Jon Reiten, assisted with water-quality data collection at all three study sites, assisted with geophysical data collection at Goose Lake study site, and provided historical data for Goose Lake and Anderson study sites.

$\underline{\text { Sheridan County Conservation District }}$

Mickey McCall, assisted with water-quality data collection at the Anderson and Goose Lake study sites, assisted with geophysical data collection at Goose Lake study site, and obtained land-access permission.

\section{$\underline{\text { USFWS }}$}

David Rouse, Region 6, Ecological Services, assisted with geophysical data collection at Goose Lake study site.

Karen Nelson, Region 6, Ecological Services, assisted with geophysical data collection at Goose Lake study site and provided historical data for Goose Lake and Anderson study sites.

\section{$\underline{\text { USGS }}$}

Ron Coffee, Crustal Geophysics and Geochemistry Science Center, assisted with geophysical data collection for Anderson and Fuller study sites.

Seth Haines, Central Energy Resources Science Center, assisted with geophysical data collection at Goose Lake study site.

Zell Peterman, Crustal Geophysics and Geochemistry Science Center, technical assistance with isotopic chemistry. 


\section{References}

Dahl, T.E., 1990, Wetland: Losses in the United States 1780's to 1980's: Washington, D.C., U.S. Department of the Interior, Fish and Wildlife Service, 13 p. (Also available at http://www.npwrc.usgs.gov/resource/wetlands/wetloss/.)

Gleason, R.A., Thamke, J.N., Smith, B.D., Tangen, B.A., Chesley-Preston, T, and Preston, T., 2011, Examination of brine contamination risk to aquatic resources from petroleum development in the Williston Basin: U.S. Geological Survey Fact Sheet 2011-3047, 4 p.

Iampen, H.T. and Rostron, B.J., 2000, Hydrogeochemistry of pre-Mississippian brines, Williston Basin, Canada-USA: Journal of Geochemical Exploration, v. 70, p. 29-35.

Fishman, M.J., and Friedman, L.C., 1989, Methods for determination of inorganic substances in water and fluvial sediments: U.S. Geological Survey Techniques of Water-Resources Investigations, book 5, chap. A1, 545 p.

Knapton, J.R., 1985, Field guidelines for collection, treatment, and analysis of water sampled, Montana District: U.S. Geological Survey Open-File Report 85-409, 86 p.

McNeill, J.D., 1980, Electromagnetic terrain conductivity measurement at low induction numbers: Geonics Technical Notes TN-6, 15 p.

Murphy, E.C., and Kehew, A.E., 1984, The effect of oil and gas well drilling fluids on shallow groundwater in western North Dakota: North Dakota Geological Survey Report of Investigation No. $82,156 \mathrm{p}$.

Peterman, Z.E., Thamke, J.N., Futa, Kiyoto, and Oliver, T.A., 2010, Strontium isotope detection of brine contamination in the East Poplar oil field, Montana: U.S. Geological Survey Open-File Report 2010-1326, 20 p. (Also available at http://pubs.usgs.gov/of/2010/1326/.)

Pollastro, R.M., Cook, T.A., Roberts, L.N., Schenk, C.J., Lewan, M.D., Anna, L.O., Gaswirth, S.B., Lillis, P.G., Klett, T.R., and Charpentier, R.R., 2008, Assessment of undiscovered oil resources in the Devonian-Mississippian Bakken Formation, Williston Basin Province, Montana and North Dakota, 2008: U.S. Geological Survey Fact Sheet 2008-3021, 2 p.

Preston, T.M., Chesley-Preston, T.L., Thamke J.N., and Peterman, Z.E., 2012, A GIS based vulnerability assessment of contamination to aquatic resources from oil and gas development in eastern Sheridan County, MT: American Water Resources Association meeting, New Orleans, 1 p.

Preston, T.M., Tangen, B.A., Chesley-Preston, T.L., Gleason, R.A., Haines, S.S.,Van der Burg, M.P. Smith, B.D. and Sodja, R.S., 2011, Risk of contamination of aquatic resources from energy development in the Williston Basin based on a spatial, chemical, and geophysical assessment: Geological Society of America Abstracts with Programs, v. 43, no. 6, p. 343.

Preston, T., Tangen, B., Chesley-Preston, T. Thamke, J., Gleason, R.A., and Smith, B.D., 2010, Risk assessment of brine contamination to aquatic resources from energy development in the Williston Basin: Geological Society of America Abstracts with Programs, v. 42, no. 5, p. 453.

Reiten, J.C., Teschmak, T., 1993, Appraisal of oil field brine contamination in shallow ground water and surface water, eastern Sheridan county, Montana: Montana Bureau of Mines and Geology OpenFile Report 260, 300 p., 2 sheets.

Smith, B.D., Thamke, J.N., Cain, M.J., Tyrrell, C., and Hill, P.L., 2006, Helicopter electromagnetic and magnetic survey maps and data, east Poplar oil field area, August 2004, Fort Peck Indian Reservation, northeastern Montana: U.S. Geological Survey Open-File Report 2006-1216. (Also available at http://pubs.usgs.gov/of/2006/1216/.)

Smith, B.D., Sodja, R.S., Gleason, R.A., Thamke, J.N., Preston, T., and Reiten, J., 2009, Brine contamination to prairie potholes from energy development in the Williston Basin: A developing 
integrated science project: Geological Society of America Abstracts with Programs, v. 41, no. 7, p. 651.

Tangen, B., Gleason, R.L., Chesley-Preston, T.L., Preston, T.M., Smith, B.D., and Thamke, J.N., 2011, Brine contamination to aquatic resources from energy development in the Williston Basin: North Dakota Chapter of the Wildlife Society Annual Meeting, Mandan, North Dakota, $1 \mathrm{p}$.

Thamke, J.N., and Craigg, S.D., 1997, Saline-water contamination in Quaternary deposits and the Poplar River, East Poplar oil field, northeastern Montana: U.S. Geological Survey Water-Resources Investigations Report 97-4000, 37 p. (Also available at http://pubs.er.usgs.gov/usgspubs/wri/wri974000.)

U.S. Fish and Wildlife Service, 2007, Waterfowl production areas: Prairie jewels of the National Wildlife Refuge System: U.S. Fish and Wildlife Service Fact Sheet, 2 p. (Also available at http://www.fws.gov/refuges/pdfs/factsheets/FactSheetWPA.pdf.)

U.S. Geological Survey, variously dated, National field manual for the collection of water-quality data: U.S. Geological Survey Techniques of Water-Resources Investigations, book 9, chaps. A1-A9. (Also available at http://water.usgs.gov/owq/FieldManual/.)

Wanty, R.B., 1997, USGS research on saline waters co-produced with energy resources: U.S. Geological Survey Fact Sheet FS-003-97. (Also available at http://pubs.usgs.gov/fs/1997/fs00397/FS-003-97.html.)

\section{Appendix 1. Water-Quality and Geophysical Data (digital data)}

The following tables are given in the digital data. The tables have self-explanatory headings. Digital data are given in folders with table number labels.

Table 1-1. Water-quality data for Goose Lake study site, Montana, 1989-2009.

Table 1-2. Water-quality data for Anderson study site, Montana, 2004, 2005, and 2010.

Table 1-3. Water-quality data for Fuller study site, North Dakota, 2010.

Table 1-4. Geophysical survey data for the Goose Lake study site, Montana (2004. 2009), for the Anderson study site, $(2004,2010)$, and for the Fuller study site (2010). 